\title{
Influence of Media Heat Sterilization Process on Growth Performance of Representative Strains of the Genus Lactobacillus
}

\author{
Martin Senz ${ }^{1, *}$, Claudia Keil ${ }^{2}$, Maximilian Schmacht ${ }^{1}$, Sophie Palinski ${ }^{2}$, Bettina Cämmerer ${ }^{3}$ \\ and Martin Hageböck ${ }^{1}$ \\ 1 Department Bioprocess Engineering and Applied Microbiology, Research and Teaching Institute for Brewing \\ in Berlin, Seestrasse 13, 13353 Berlin, Germany; m.schmacht@vlb-berlin.org (M.S.); \\ m.hageboeck@vlb-berlin.org (M.H.) \\ 2 Department of Food Chemistry and Toxicology, Institute of Food Technology and Food Chemistry, \\ Berlin Institute of Technology, Gustav-Meyer-Allee 25, 13355 Berlin, Germany; c.keil@tu-berlin.de (C.K.); \\ sophie.palinski@web.de (S.P.) \\ 3 Department of Food Chemistry and Analytics, Institute of Food Technology and Food Chemistry, \\ Berlin Institute of Technology, Gustav-Meyer-Allee 25, 13355 Berlin, Germany; \\ bettina.caemmerer@tu-berlin.de \\ * Correspondence: m.senz@vlb-berlin.org; Tel.: +49-30-45080-153
}

Received: 27 December 2018; Accepted: 11 February 2019; Published: 15 February 2019

\begin{abstract}
Lactic acid bacteria (LAB) are widely applied microorganisms in food, feed, and beverage applications, where they can provide essential functionality for product modification, increase product shelf life, or act as beneficial organisms after consumption. Among these, strains of the genus Lactobacillus are often used as starters, probiotics, or biopreservatives. For all these types of bacterial preparations, a transportable shelf-stable form of concentrated bacteria, preserving their intrinsic properties, is essential for commercial distribution. Former studies revealed a relationship between the culture medium, cellular morphology, and the robustness of Lactobacillus acidophilus NCFM (name derived from North Carolina Food Microbiology) cultures. Due to these insights, a multitude of Lactobacillus strains representative of the genus were screened regarding their sensitivity to thermal medium pretreatment possibly accompanied by the alteration of their chemical composition, such as the formation of Maillard reaction products (MRPs). This study reveals a quite diverse and different growth behavior of those strains in the form of altered or non-altered cell concentrations and the size distributions of the populations, whereby five strains of the L. delbrueckii group in particular showed increased cell concentrations combined with decreased mean cell volumes. The results are of both scientific and industrial relevance, as they highlight the necessity to consider and understand the effects of media sterilization for the applied production strain.
\end{abstract}

Keywords: medium heat sterilization; medium filtration; lactic acid bacteria; Lactobacillus; cell morphology; MRS

\section{Introduction}

Lactobacillus is one of the most important genera of lactic acid bacteria (LAB) used in diverse food and agricultural applications, for example, as starter cultures, probiotics, or biopreservatives [1-3]. To ensure the functionality of the bacteria, an appropriate viability is a prerequisite. This is even more important keeping in mind that lactobacilli have relatively high nutritional demands and that many species lost the ability to synthesize diverse amino acids, cofactors, and vitamins during their evolutionary adaption to their natural habitats, which are often the human or animal gastrointestinal 
tract and plants [4,5]. Due to its industrial relevance, this genus is of utmost interest in current research. The number of newly described Lactobacillus species is constantly rising, from 152 to more than 190 in the last few years, and their biotechnological suitability needs to be considered [6,7]. Thus, intense scientific research is conducted using strains of the genus Lactobacillus in fields such as wine fermentation [8], sourdough fermentation [3,9], or cocoa bean fermentation [10]. There are several studies available describing the effects of media components or special auxotrophies of Lactobacillus strains resulting in different cell morphologies during cultivation. Depending on the corresponding species, the requirements for adequate cell division and growth can be the presence of certain divalent cations [11,12], amino acids [13], vitamins [14,15], nucleotides [16-18], and growth factors such as oleic acid sources [19]. From an industrial point of view, suppliers of lactobacilli are requested to provide highly concentrated cultures with adequate properties; the latter defined amongst others by good metabolic activity as well as high robustness against stress occurring during and after processing.

Previous studies revealed strong interrelations between the applied culture medium and the cell morphology and stability of L. acidophilus NCFM cultures during freezing, drying, and storage of the corresponding bacterial preparations [20]. In the same study it was also demonstrated that the growth performance-including the formation of populations with small mean cell sizes-was positively affected by applying a media heat sterilization process and thus probably related to Maillard reaction products (MRPs). From an industrial point of view, the extraordinary relevance of lactic acid bacteria makes it essential to broaden understanding of to what extent different strains of Lactobacillus species might be influenced in their growth behavior by thermal media pretreatment in general.

The aim of this study was to investigate the general impact of media heat treatment on the growth properties of different Lactobacillus strains, focusing on the two culture characteristics of cell concentration and mean cell size.

\section{Materials and Methods}

\subsection{Bacterial Strains}

For the screening study, 24 different strains of lactobacilli were obtained from the internal strain collection of the Department for Bioprocess Engineering and Applied Microbiology of the Research and Teaching Institute for Brewing (VLB) in Berlin. The microorganisms and the applied cultivation temperatures are listed in Table 1.

\subsection{Culture Media}

MRS medium according to De Man et al. (1960) [21] from Difco ${ }^{\mathrm{TM}}$ (Becton Dickinson GmbH (BD), Heidelberg, Germany), here called MRSD, was used for pre-cultivation and for the screening studies. The MRSD contained $10 \mathrm{~g}$ proteose peptone no.3, $10 \mathrm{~g}$ beef extract, $5 \mathrm{~g}$ yeast extract, $20 \mathrm{~g}$ dextrose, $1 \mathrm{~g}$ polysorbate 80, $2 \mathrm{~g}$ ammonium citrate, $5 \mathrm{~g}$ sodium acetate, $0.1 \mathrm{~g}$ magnesium sulfate, $0.05 \mathrm{~g}$ manganese sulfate, and $2 \mathrm{~g}$ dipotassium phosphate per liter at $\mathrm{pH}=6.5$. For the pre-culturing and for the screening studies, media were either sterilized in $1 \mathrm{~L}$ bottles at $121{ }^{\circ} \mathrm{C}$ for 20 min, here designated as MRSDa, or sterile-filtered at a pore size of $0.22 \mu \mathrm{m}$, designated as MRSDf. Additionally, sterile-filtered medium containing separately preheated $\left(121^{\circ} \mathrm{C}, 20 \mathrm{~min}\right)$ glucose-peptone mixture was used. In detail; MRSDf medium was prepared without added dextrose and proteose peptone no. 3 in $90 \%$ of the water, sterile-filtered, and afterwards supplemented with $10 \%(v / v)$ of a tenfold concentrated solution of dextrose and proteose peptone no.3 that was previously autoclaved.

\subsection{Culture Conditions}

To prepare the pre-cultures, $10 \mathrm{~mL}$ of pre-warmed MRSDa medium was inoculated with $100 \mu \mathrm{L}$ of a glycerol stock culture and incubated for $24 \mathrm{~h}$ at 30 or $37^{\circ} \mathrm{C}$ (depending on the strain; see Table 1), respectively, in gas-tight tubes. For the main batch fermentations, the pre-cultures were centrifuged for $2 \mathrm{~min}$ at $1780 \times g$ and washed with $0.89 \%(w / v) \mathrm{NaCl}$ solution. After repetition of this washing 
step, $15 \mathrm{~mL}$ screw-cap tubes filled with $10 \mathrm{~mL}$ of pre-warmed culture medium were inoculated with $10^{7}$ cells $/ \mathrm{mL}$ and incubated at the recommended growth temperature of the corresponding strain (see Table 1) for 18 and $22 \mathrm{~h}$, respectively.

Table 1. Investigated species and strains of the genus Lactobacillus for the screening of candidates' response to thermal media treatment.

\begin{tabular}{|c|c|c|c|c|}
\hline Name & $\begin{array}{l}\text { Applied Growth } \\
\text { Temperature }\end{array}$ & $\begin{array}{c}\text { Phylogenetic } \\
\text { Group }\end{array}$ & $\begin{array}{c}\text { Main Habitat or } \\
\text { Source of } \\
\text { Isolation }{ }^{* *}\end{array}$ & $\begin{array}{c}\text { Type of } \\
\text { Fermentation } * *\end{array}$ \\
\hline L. acidophilus La-0103 & $37^{\circ} \mathrm{C}$ & delb & $\mathrm{I}, \mathrm{F}$ & a \\
\hline L. acidophilus La-0107 & $37^{\circ} \mathrm{C}$ & delb & $\mathrm{I}, \mathrm{F}$ & a \\
\hline L. acidophilus NCFM & $37^{\circ} \mathrm{C}$ & delb & $\mathrm{I}, \mathrm{F}$ & a \\
\hline L. brevis La-0410 & $30{ }^{\circ} \mathrm{C}$ & bre & F, D & c \\
\hline L. buchneri La-1501 & $37^{\circ} \mathrm{C}$ & buch & F, D & c \\
\hline L. casei subsp. alactosus La-0605 & $30{ }^{\circ} \mathrm{C}$ & cas & $\mathrm{F}$ & $\mathrm{b}$ \\
\hline L. casei subsp. casei La-0618 & $30^{\circ} \mathrm{C}, 37^{\circ} \mathrm{C}$ & cas & $\mathrm{F}$ & $\mathrm{b}$ \\
\hline L. confusus La-2201 (Weissella confusa) & $30{ }^{\circ} \mathrm{C}$ & - & $\mathrm{F}, \mathrm{I}, \mathrm{S}$ & c \\
\hline L. curvatus La-1001 & $30{ }^{\circ} \mathrm{C}$ & sakei & $\mathrm{I}, \mathrm{F}, \mathrm{D}$ & $\mathrm{b}$ \\
\hline L. delbrueckii subsp. bulgaricus La-0502 & $37^{\circ} \mathrm{C}$ & delb & $\mathrm{F}$ & a \\
\hline L. delbrueckii subsp. delbrueckii La-0704 & $37^{\circ} \mathrm{C}$ & delb & $\mathrm{F}$ & a \\
\hline L. delbrueckii subsp. lactis La-07/102 & $37^{\circ} \mathrm{C}$ & delb & $\mathrm{F}$ & a \\
\hline L. farciminis La-3401 & $30{ }^{\circ} \mathrm{C}$ & al-far & $\mathrm{F}$ & a \\
\hline L. johnsonii La-2801 & $37^{\circ} \mathrm{C}$ & delb & $\mathrm{I}, \mathrm{F}$ & a \\
\hline L. kefiri La-2601 & $30{ }^{\circ} \mathrm{C}$ & buch & $\mathrm{F}$ & c \\
\hline L. pentosus La-3301 & $30{ }^{\circ} \mathrm{C}$ & plan & $\mathrm{F}, \mathrm{S}$ & $\mathrm{b}$ \\
\hline L. plantarum La-1203 & $30{ }^{\circ} \mathrm{C}$ & plan & F, D & $\mathrm{b}$ \\
\hline L. plantarum La-1210 & $37^{\circ} \mathrm{C}$ & plan & F, D & $\mathrm{b}$ \\
\hline L. rhamnosus La-0610 & $37^{\circ} \mathrm{C}$ & cas & $\mathrm{F}$ & $\mathrm{b}$ \\
\hline L. rhamnosus La-0611 & $37^{\circ} \mathrm{C}$ & cas & $\mathrm{F}$ & $\mathrm{b}$ \\
\hline L. rhamnosus La-0617 & $37^{\circ} \mathrm{C}$ & cas & $\mathrm{F}$ & $\mathrm{b}$ \\
\hline L. rhamnosus La-0619 & $37^{\circ} \mathrm{C}$ & cas & $\mathrm{F}$ & $\mathrm{b}$ \\
\hline L. ruminis La-2101 & $37^{\circ} \mathrm{C}$ & sal & I & a \\
\hline L. salivarius subsp. salivarius La-2002 & $37^{\circ} \mathrm{C}$ & sal & I & a \\
\hline
\end{tabular}

* According to [22] ** According to Bergey's Manual of Systematic Bacteriology [23] (delb) L. delbrueckii group; (sal)

L. salivarius group; (reu) L. reuteri group; (buch) L. buchneri group; (al-far) L. alimentarius - L. farciminis group; (cas) L. casei group; (sakei) L. sakei group; (plan) L. plantarum group; (bre) L. brevis group; D: food-associated, usually involved in spoilage; F: involved in fermentation of food and feed; I: associated with humans and/or animals (e.g., oral cavity, intestines, vagina); S: sewage; a: obligately homofermentative; b: facultatively heterofermentative; c: obligately heterofermentative.

\subsection{Determination of the Total Cell Concentration and Cell Volume Distribution}

The total cell concentration ( $\mathrm{cc}$; in cells $/ \mathrm{mL}$ ), cell size distribution and mean cell volume (mcv; in $\mu \mathrm{m}^{3}$ ) were determined with a Beckman Multisizer ${ }^{\mathrm{TM}} 3$ Coulter Counter ${ }^{\circledR}$ (Beckman Coulter GmbH, Krefeld, Germany) with a capillary diameter of $20 \mu \mathrm{m}$. The pulse data were converted to size features using the Multisizer ${ }^{\mathrm{TM}} 3$ software version 3.53 (Beckman Coulter $\mathrm{GmbH}$, Krefeld, Germany). For a better evaluation of the growth behavior in the two tested media, the cell concentration (cc) ratios in MRSDa and MRSDf were calculated and stated for each strain. The same assessment was done for the mean cell volume (mcv).

\subsection{Scanning Electron Microscope Images}

Samples of the corresponding cultures were prepared via freeze-drying as described previously [20], and dried samples were coated with gold using the Sputter Coater JEOL JFC-1200 (JEOL Ltd., Tokyo, Japan). Subsequently, scanning electron microscope (SEM) images were acquired on a JSM-6610LV Scanning Electron Microscope (JEOL Ltd., Tokyo, Japan), equipped with a tungsten filament gun, operating at $10.0 \mathrm{~mm}$ WD and $5 \mathrm{kV}$. 


\section{Results and Discussion}

Heat sterilization is a very common process to obtain adequate culture media for LAB production [24]. The application of reducing sugars like $\mathrm{D}_{\mathrm{D}}$-glucose as the carbon source in the presence of amino-rich components inevitably leads to the generation of MRPs and therefore to changes in the physicochemical media characteristics when sterilizing them by heat treatment [25]. Thereby the thermal products created (e.g., melanoidins) were proven to be antimicrobial or inhibitory agents on the growth of Escherichia coli and certain hyperthermophilic archaea [26,27]. For bifidobacteria and selected LAB, the addition of growth components glycated via Maillard reaction was obviously beneficial for growth performance [28]. Moreover, previous studies indicated that the media heat treatment had significant positive consequences for the growth behavior of L. acidophilus NCFM and the robustness of the Lactobacillus cultures obtained. Therefore, increasing the understanding of the interrelation between the media sterilization procedure and the culture characteristics is of significant scientific interest, and is also important from an economic point of view. Consequently, 24 Lactobacillus strains were studied for their sensitivity to the heat products occurring via the heat treatment of the fermentation medium, and the formation of those products was assured by autoclaving all the ingredients together.

After fermentation of the 24 different Lactobacillus strains (see Table 1) a clear variability in growth characteristics was observed. As expected, these differences were generally apparent between different species. Figure 1 summarizes the mean cell sizes and cell concentrations of the screened strains after a $22 \mathrm{~h}$ growth and Figure 2 highlights the differences obtained in the two tested media. Comparable results were also achieved upon a shorter incubation period of $18 \mathrm{~h}$ (data not shown). Some of the cultures showed increased cell concentrations when grown in MRSD medium that was only sterile-filtered (e.g., L. rhamnosus La-0617), some were not affected at all (e.g., L. pentosus La-3301), and certain strains showed beneficial growth behavior in heat-sterilized media and thus in the presence of thermal reaction products like MRPs (e.g., L. acidophilus NCFM).

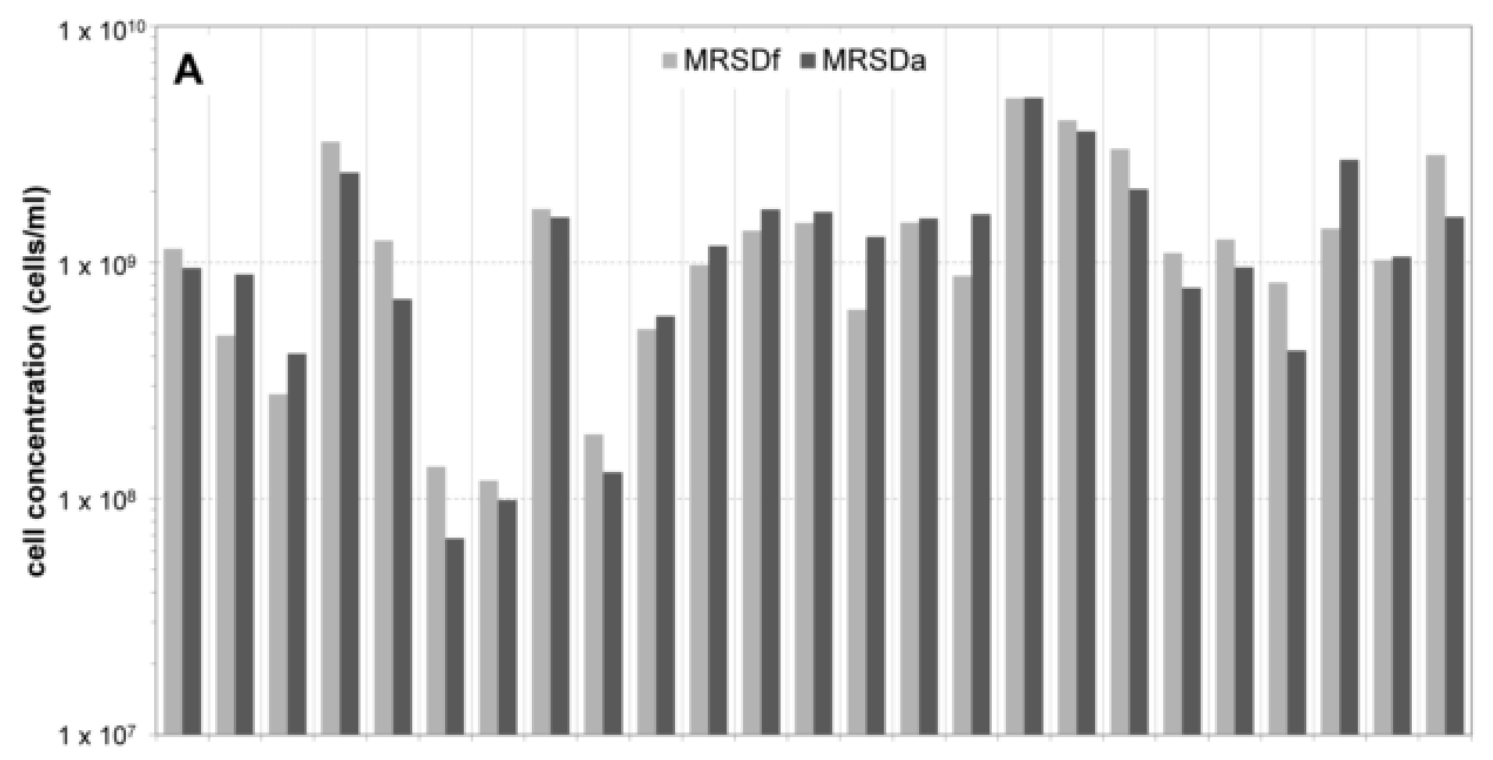

Figure 1. Cont. 


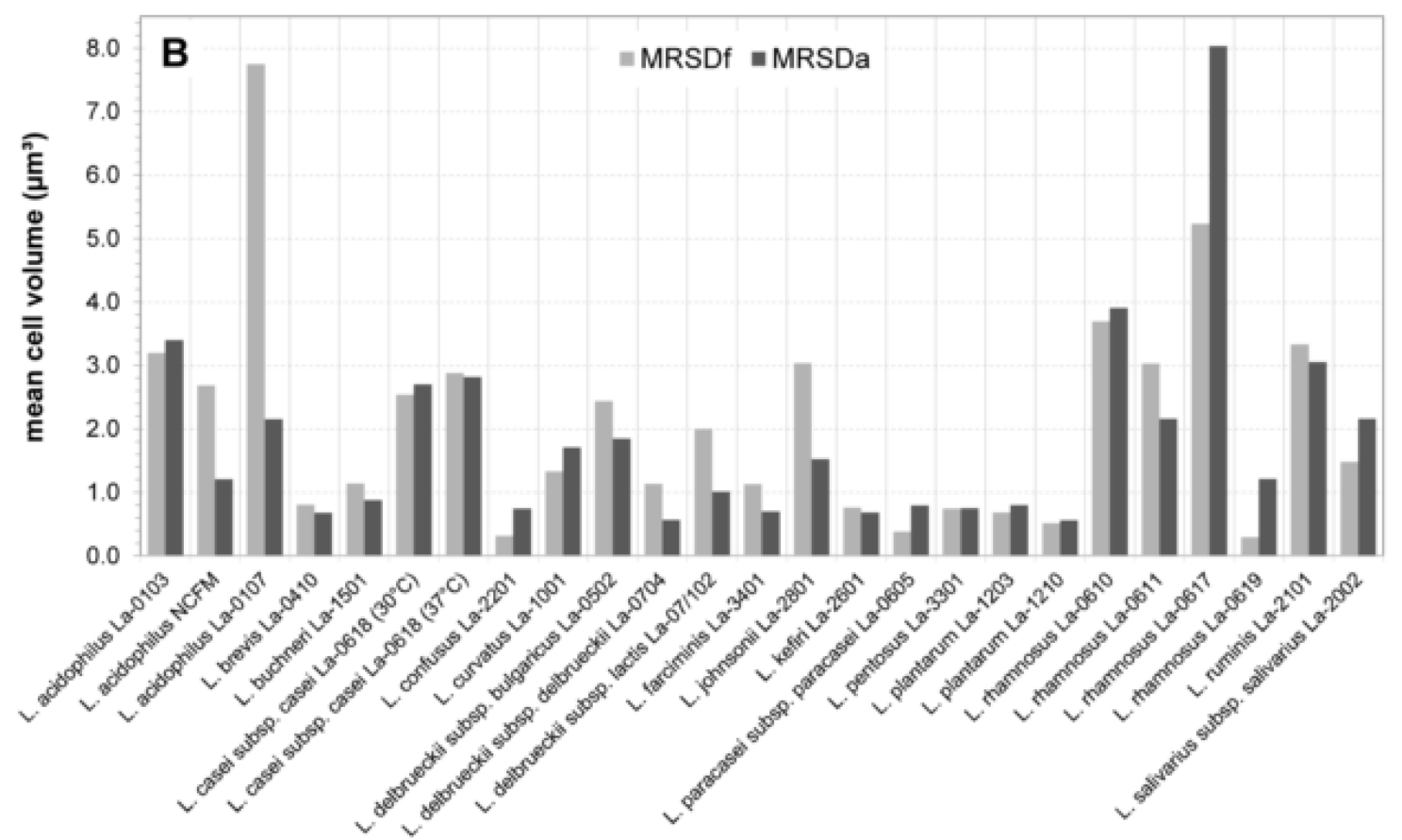

Figure 1. Growth characteristics (A: cell concentration; B: mean cell size) of the 24 screened Lactobacillus strains grown in autoclaved (MRSDa) and sterile-filtered (MRSDf) MRS medium for $22 \mathrm{~h}$.

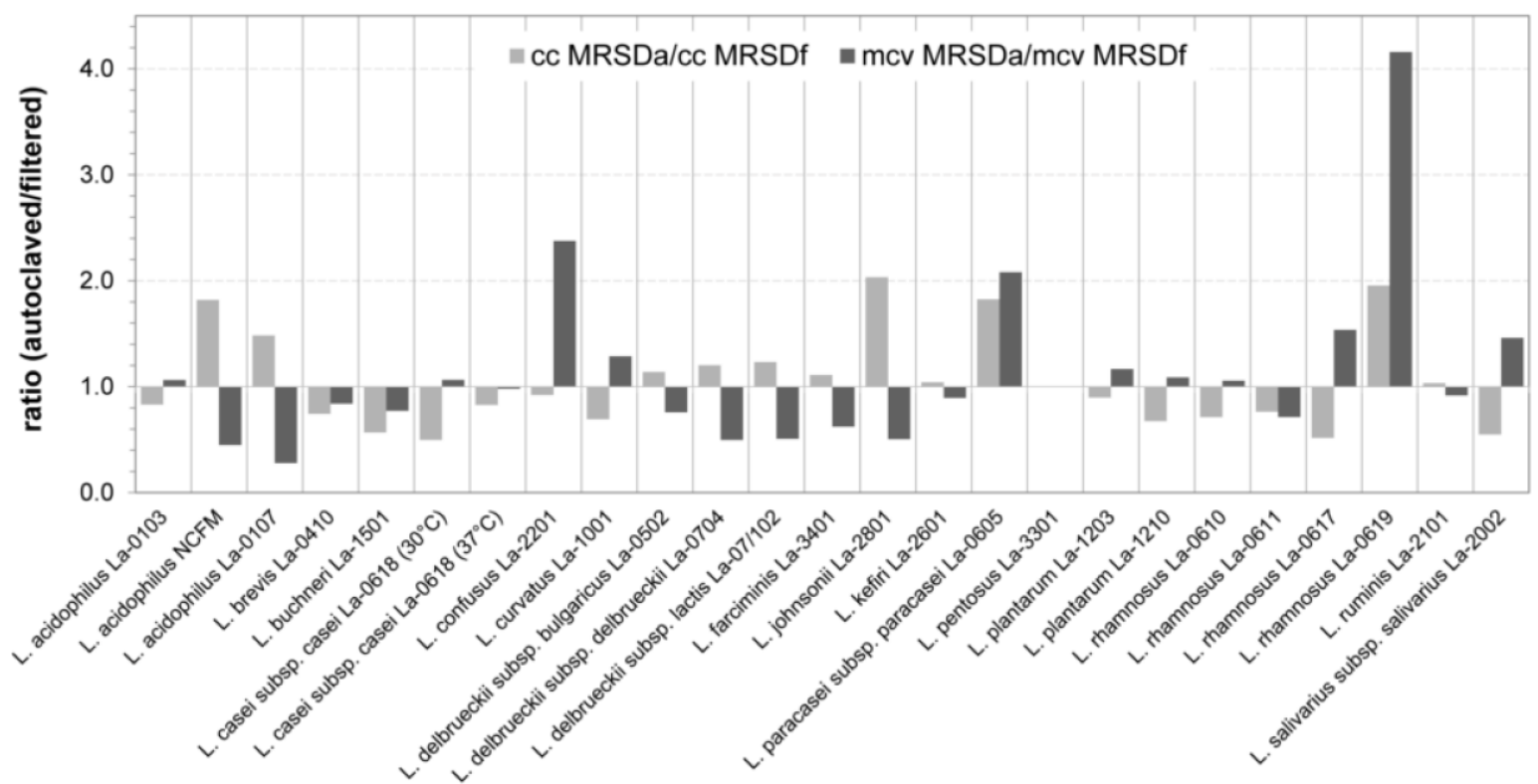

Figure 2. Growth characteristics of the screened lactobacilli illustrated as a ratio of the corresponding parameter in the autoclaved and filtered medium, respectively. The ratio was calculated for the parameters cell concentration (cc) and mean cell volume (mcv), respectively.

Figure 3 depicts examples of mean cell size and size distribution of two lactobacilli strains sensitive (L. johnsonii La-2801) or non-sensitive (L. plantarum La-1203) to heating-induced MRSD medium components. In the case of L. plantarum, the data emphasize that both prepared media fulfilled the nutritional requirements, as recent data showed there was morphological variability of L. plantarum under nutrient stress conditions [29]. Additionally, Figure 1a depicts a rather recurrent phenomenon - that lactobacilli populations with smaller mean cell sizes have comparatively higher cell densities, which has previously been observed for L. acidophilus NCFM [20]. Moreover, scanning electron microscope pictures substantiated this observation (Figure 4). Although it is difficult to 
identify clear universal correlations with the available data, it seems apparent that species of the phylogenetic L. delbrueckii group (L. acidophilus, L. delbrueckii subsp. lactis, L. johnsonii) that have wider amino acid requirements [22] are susceptible to generating shorter rods in the stationary growth phase in heat-treated MRSD, compared to species with fewer amino acid needs (L. pentosus, L. plantarum; both belonging to the phylogenetic L. plantarum group) [30,31], which showed no differences in cell size or concentration in filtered and autoclaved media (Figure 1). The only species that revealed an unwanted growth behavior in heat-treated MRSD was L. rhamnosus, whereby two of three strains tended to a pronounced filamentation of the cells (Figure 1b). The experiment also confirmed the previously described growth performance of L. acidophilus NCFM [20]. Nevertheless, based on the available data, no generalization of species-dependent behavior is possible, as some strains of the same species seemed to perform non-uniformly (e.g., the species L. acidophilus and L. rhamnosus in Figure 2).

The results of the screening study were substantiated by further experiments with 3 out of the 24 tested strains. Namely, L. delbrueckii subsp. Delbrueckii La-0704, L. acidophilus La-0107, and L. johnsonii La-2801. All three strains were grown in MRSDa, MRSDf, or MRSDf supplemented with preheated glucose-peptone mixtures (Figure 5). Again, the impact of medium preparation on cell morphology was displayed. It was clearly shown that the heat treatment of the media had a statistically significant influence on the cell count as well as the cell volume compared to growth in sterile-filtered media. Further, the study revealed the significant impact of heat products formed during the heating of the medium ingredients glucose and peptone, indicating a connection to MRPs [25]. The latter aspect was further reinforced by the observation of a much stronger browning of the filtered medium supplemented with the separately heated glucose-peptone mixture-a phenomenon that will be evaluated in subsequent and separate investigations elsewhere.
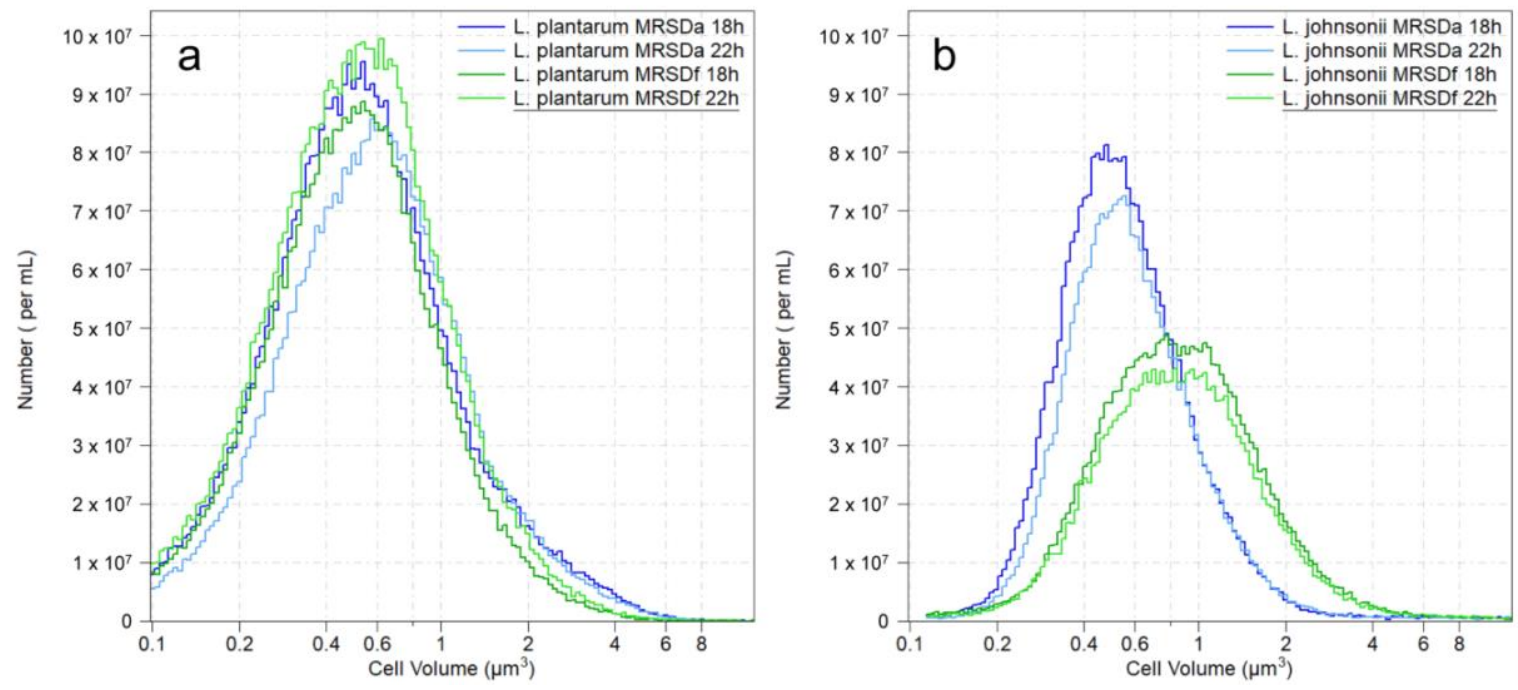

Figure 3. Cell concentration and size distribution of (a) L. plantarum La-1203 and (b) L. johnsonii La-2801 grown for 18 and $22 \mathrm{~h}$ in sterile-filtered (MRSDf) and autoclaved (MRSDa) medium, representing strains that are (a) non-sensitive and (b) sensitive to heating-induced MRSD components. 


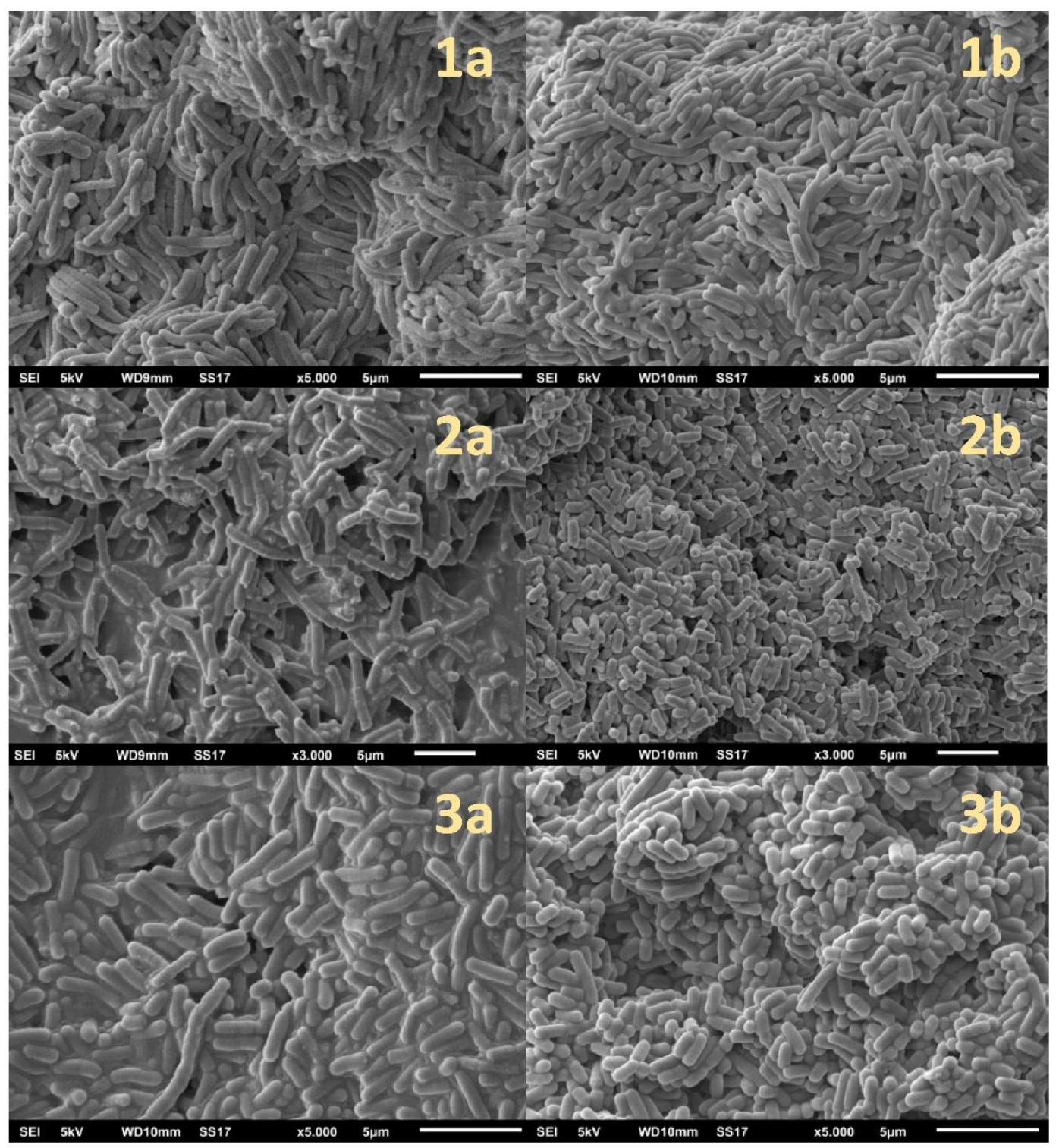

Figure 4. Scanning electron microscopy pictures of three candidates responding to thermal media treatment: L. delbrueckii subsp. delbrueckii La-0704 (1), L. acidophilus La-0107 (2), and L. johnsonii La-2801 (3) grown for $22 \mathrm{~h}$ in sterile-filtered (a) and autoclaved (b) MRSD. 

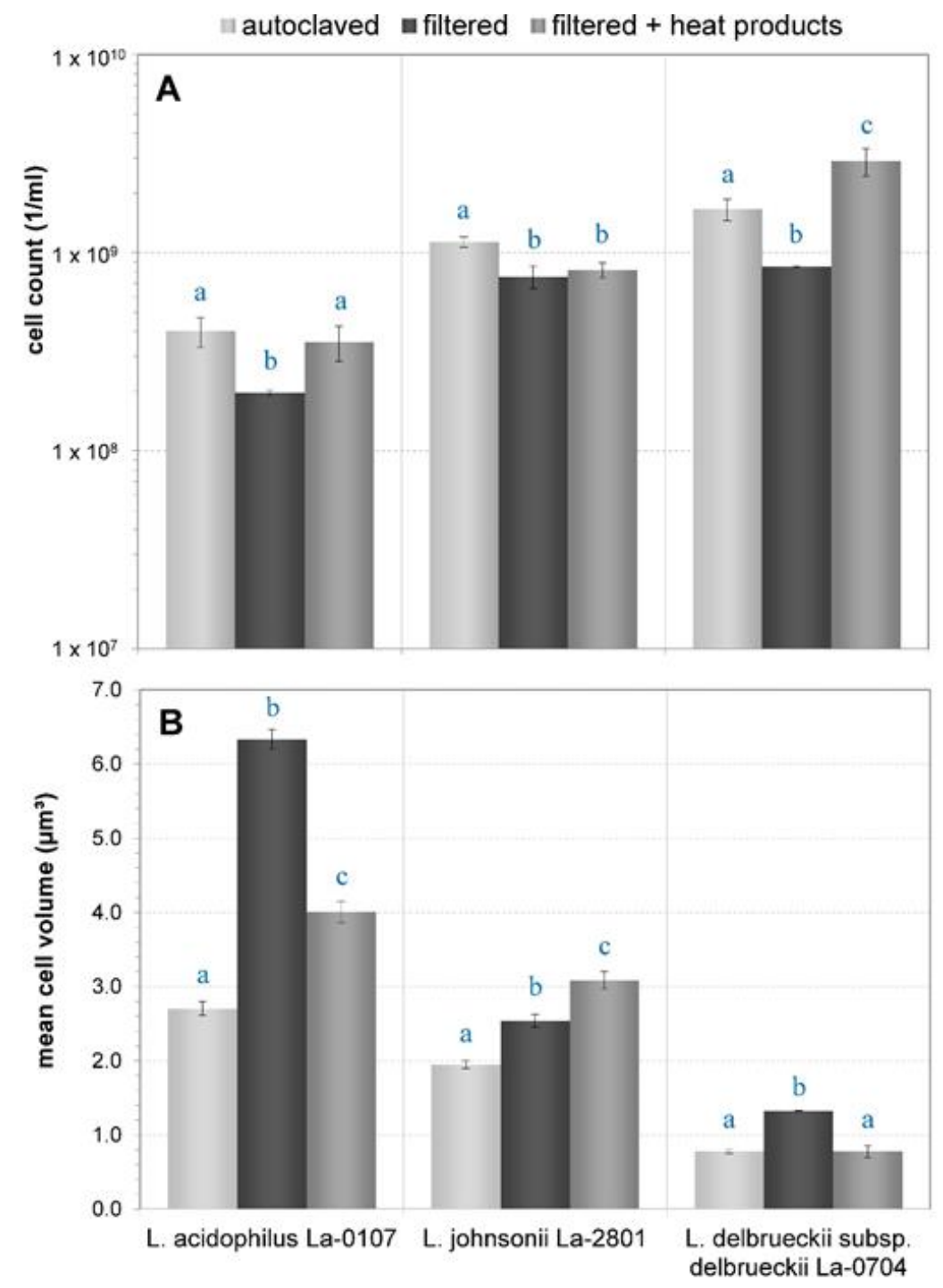

Figure 5. Growth characteristics (A: cell concentration; B: mean cell size) of three lactobacilli candidate strains grown for $22 \mathrm{~h}$ in either autoclaved MRSD, sterile-filtered MRSD, or sterile-filtered MRSD supplemented with separately preheated glucose-peptone mixture, with the latter supplying heat-induced products. The data represent the mean values \pm SD of three biological replicates. The same small letter represents identical populations of the corresponding parameter between investigated strains (Mood's median test, $\alpha=0.05$ ).

Altogether, the results illustrate that the heat treatment of the growth medium can affect the growth behavior of lactobacilli. Such knowledge about promoted or reduced growth can be used by the dairy industry to enhance the selectiveness of the growth medium milk. Early studies by Foster et al. (1952) revealed very inhomogeneous growth behavior of different LAB in heated and non-heated milk-information that can be used to prevent the prevalent growth of mesophilic non-starter lactobacilli [32,33].

In brief, the results of the screening study indicated that out of 24 tested strains, five were influenced positively or negatively to a degree of more than $50 \%$ in cell concentration, and seven were influenced positively or negatively in the mean cell size by more than $50 \%$ when applying heat-sterilized MRSD medium. Interestingly, five strains showed a clearly increased cell concentration combined with a decreased mcv (Figure 2). Keeping in mind that these characteristics can potentially affect the viability and vitality of the cultures following multi-processing steps (e.g., production of bacteria preparations), the role of media sterilization and especially heat-induced performance in the 
process of industrial lactobacilli development needs to be considered in detail. The characterization of thermally treated MRSD media with regard to Maillard intermediates is currently underway. Along with further studies on the MRP sensitive Lactobacillus strains L. delbrueckii subsp. delbrueckii La-0704, L. acidophilus La-0107, and L. johnsonii La-2801, those data will give an insight into how far especially industrially relevant Lactobacillus starters or probiotics can be positively affected in their cell morphology and stability by the media preparation procedure.

\section{Conclusions}

For the industrial production of lactobacilli, fastidious nutritional requirements have to be considered to get high-density cultures with the desired properties. The usage of complex media that fulfill these requirements as well as heat processing is common praxis, so the formation of heat products to a certain degree is often unavoidable. In a simple microbial test system, where the common Lactobacillus growth medium was used in a sterile-filtered form and in an autoclaved form (following the manufacturer's advice), the sensitivity of 24 different Lactobacillus strains due to the altered chemical composition (e.g., due to the formation of MRPs) was investigated. Thereby, five strains were clearly affected in the final cell concentration, and seven showed differences in the mean cell sizes after $22 \mathrm{~h}$ growth (stationary growth phase). Further studies verified the significant influence of the media heat treatment and revealed a certain connection to components formed during the heating of glucose and peptone. The affected cell characteristics are relevant from an economic point of view, and can have an impact on bacterial robustness. The fact that the heat treatment of the medium influences different Lactobacillus species in a direct or indirect way highlights that this phenomenon should be taken into consideration during the fermentation process development. In our opinion, this is an underestimated research topic that still needs systematic examination.

Author Contributions: M.Se. and M.H. conceptualized the study and acquired the funding. S.P. conducted and analyzed the experiments. M.Se., C.K., M.Sc., and B.C. supervised and analyzed the experiments. M.H. conducted the SEM depiction. M.Se., C.K. and M.Sc. wrote the manuscript. All authors read and approved the final manuscript.

Funding: This research and parts of the equipment were funded by the German Federal Ministry for Economic Affairs and Energy and the Euronorm GmbH (program INNO-KOM OST; research project MikroMail; funding no.: VF150026; funding no.: IZ130010).

Acknowledgments: The authors thank Patrick Feige and Felix Horlitz for the technical assistance.

Conflicts of Interest: The authors declare no conflict of interest. The funders had no role in the design of the study; in the collection, analyses, or interpretation of data; in the writing of the manuscript, or in the decision to publish the results.

\section{References}

1. Arena, M.P.; Caggianiello, G.; Russo, P.; Albenzio, M.; Massa, S.; Fiocco, D.; Capozzi, V.; Spano, G. Functional Starters for Functional Yogurt. Foods 2015, 4, 15-33. [CrossRef]

2. Pasini, F.; Soglia, F.; Petracci, M.; Caboni, M.F.; Marziali, S.; Montanari, C.; Gardini, F.; Grazia, L.; Tabanelli, G. Effect of Fermentation with Different Lactic Acid Bacteria Starter Cultures on Biogenic Amine Content and Ripening Patterns in Dry Fermented Sausages. Nutrients 2018, 10, 1497. [CrossRef] [PubMed]

3. Russo, P.; Fares, C.; Longo, A.; Spano, G.; Capozzi, V. Lactobacillus plantarum with Broad Antifungal Activity as a Protective Starter Culture for Bread Production. Foods 2017, 6, 110. [CrossRef] [PubMed]

4. Claesson, M.J.; van Sinderen, D.; O'Toole, P.W. Lactobacillus phylogenomics-Towards a reclassification of the genus. Int. J. Syst. Evol. Microbiol. 2008, 58, 2945-2954. [CrossRef] [PubMed]

5. Bull, M.; Plummer, S.; Marchesi, J.; Mahenthiralingam, E. The life history of Lactobacillus acidophilus as a probiotic: A tale of revisionary taxonomy, misidentification and commercial success. FEMS Microbiol. Lett. 2013, 349, 77-87. [CrossRef] [PubMed]

6. Salvetti, E.; Torriani, S.; Felis, G.E. The genus Lactobacillus: A taxonomic update. Probiot. Antimicrob. Proteins 2012, 4, 217-226. [CrossRef] [PubMed] 
7. Salvetti, E.; O'Toole, P.W. When regulation challenges innovation: The case of the genus Lactobacillus. Trends Food Sci. Technol. 2017, 66, 187-194. [CrossRef]

8. Cappello, M.S.; Zapparoli, G.; Logrieco, A.; Bartowsky, E.J. Linking wine lactic acid bacteria diversity with wine aroma and flavour. Int. J. Food Microbiol. 2017, 243, 16-27. [CrossRef] [PubMed]

9. Nionelli, L.; Montemurro, M.; Pontonio, E.; Verni, M.; Gobbetti, M.; Rizzello, C.G. Pro-technological and functional characterization of lactic acid bacteria to be used as starters for hemp (Cannabis sativa L.) sourdough fermentation and wheat bread fortification. Int. J. Food Microbiol. 2018, 279, 14-25. [CrossRef] [PubMed]

10. Romanens, E.; Freimüller Leischtfeld, S.; Volland, A.; Stevens, M.J.A.; Krähenmann, U.; Isele, D.; Fischer, B.; Meile, L.; Miescher Schwenninger, S. Screening of lactic acid bacteria and yeast strains to select adapted anti-fungal co-cultures for cocoa bean fermentation. Int. J. Food Microbiol. 2019, 290, 262-272. [CrossRef]

11. Wright, C.T.; Klaenhammer, T.R. Calcium-induced alteration of cellular morphology affecting the resistance of Lactobacillus acidophilus to freezing. Appl. Environ. Microbiol. 1981, 41, 807-815. [PubMed]

12. Wright, C.T.; Klaenhammer, T.R. Influence of calcium and manganese on dechaining of Lactobacillus bulgaricus. Appl. Environ. Microbiol. 1983, 46, 785-792. [PubMed]

13. Savijoki, K.; Ingmer, H.; Varmanen, P. Proteolytic systems of lactic acid bacteria. Appl. Microbiol. Biotechnol. 2006, 71, 394-406. [CrossRef] [PubMed]

14. Kusaka, I.; Kitahara, K. Effect of several vitamins on the cell division and the growth of Lactobacillus delbrueckii. J. Vitaminol. 1962, 8, 115-120. [CrossRef]

15. Deibel, R.H.; Downing, M.; Niven, C.F., Jr.; Schweigert, B.S. Filament formation by Lactobacillus leichmannii when desoxyribosides replace vitamin B12 in the growth medium. J. Bacteriol. 1956, 71, 255-256. [PubMed]

16. Ives, D.H.; Ikeda, S. Life on the salvage path: Deoxynucleoside kinases of Lactobacillus acidophilus R-26. Prog. Nucleic Acid Res. Mol. Biol. 1997, 59, 205-255. [CrossRef]

17. Reich, J.; Soska, J. Thymineless death in Lactobacillus acidophilus R-26. II. Factors determining the rate of the reproductive inactivation. Folia Microbiol. (Praha) 1973, 18, 361-367. [CrossRef] [PubMed]

18. Jeener, H.; Jeener, R. Cytological study of Thermobacterium acidophilus R 26 cultured in absence of deoxyribonucleosides or uracil. Exp. Cell Res. 1952, 3, 675-680. [CrossRef]

19. Jacques, N.A.; Hardy, L.; Knox, K.W.; Wicken, A.J. Effect of Tween 80 on the morphology and physiology of Lactobacillus salivarius strain IV CL-37 grown in a chemostat under glucose limitation. J. Gen. Microbiol. 1980, 119, 195-201. [CrossRef]

20. Senz, M.; van Lengerich, B.; Bader, J.; Stahl, U. Control of cell morphology of probiotic Lactobacillus acidophilus for enhanced cell stability during industrial processing. Int. J. Food Microbiol. 2015, 192, 34-42. [CrossRef]

21. De Man, J.C.; Rogosa, M.; Sharpe, M. A medium for the cultivation of lactobacilli. J. Appl. Microbiol. 1960, 23, 130-135. [CrossRef]

22. Felis, G.E.; Dellaglio, F. Taxonomy of Lactobacilli and Bifidobacteria. Curr. Issues Intest. Microbiol. 2007, 8, 44-61. [PubMed]

23. Vos, P.; Garrity, G.; Jones, D.; Krieg, N.R.; Ludwig, W.; Rainey, F.A.; Schleifer, K.-H.; Whitman, W.B. Bergey's Manual of Systematic Bacteriology: Volume 3: The Firmicutes; Springer Science \& Business Media: New York, NY, USA, 2011.

24. Bylund, G. Dairy Processing Handbook; Tetra Pak Processing Systems AB: Lund, Sweden, 1995.

25. Hellwig, M.; Henle, T. Baking, ageing, diabetes: A short history of the Maillard reaction. Angew. Chem. Int. Ed. 2014, 53, 10316-10329. [CrossRef] [PubMed]

26. Rurián-Henares, J.A.; Morales, F.J. Antimicrobial activity of melanoidins against Escherichia coli is mediated by a membrane-damage mechanism. J. Agric. Food Chem. 2008, 56, 2357-2362. [CrossRef] [PubMed]

27. Kim, K.W.; Lee, S.B. Inhibitory Effect of Maillard reaction products on growth of the aerobic marine hyperthermophilic archaeon Aeropyrum pernix. Appl. Environ. Microbiol. 2003, 69, 4325. [CrossRef] [PubMed]

28. Corzo-Martínez, M.; Ávila, M.; Moreno, F.J.; Requena, T.; Villamiel, M. Effect of milk protein glycation and gastrointestinal digestion on the growth of bifidobacteria and lactic acid bacteria. Int. J. Food Microbiol. 2012, 153, 420-427. [CrossRef] [PubMed]

29. Parlindungan, E.; Dekiwadia, C.; Tran, K.T.M.; Jones, O.A.H.; May, B.K. Morphological and ultrastructural changes in Lactobacillus plantarum B21 as an indicator of nutrient stress. LWT 2018, 92, 556-563. [CrossRef] 
30. Hébert, E.M.; Raya, R.R.; de Giori, G.S. Nutritional requirements of Lactobacillus delbrueckii subsp. lactis in a chemically defined medium. Curr. Microbiol. 2004, 49, 341-345. [CrossRef]

31. Møretrø, T.; Hagen, B.F.; Axelsson, L. A new, completely defined medium for meat lactobacilli. J. Appl. Microbiol. 2004, 85, 715-722. [CrossRef]

32. Foster, E.M. The effect of heat on milk as a Culture medium for lactic acid bacteria. J. Dairy Sci. 1952, 35, 988-997. [CrossRef]

33. Stulova, I.; Kabanova, N.; Kriščiunaite, T.; Laht, T.M.; Vilu, R. The effect of milk heat treatment on the growth characteristics of lactic acid bacteria. Agron. Res. 2011, 9, 473-478. 